\title{
IMPLEMENTASI ISLAMIC SOCIAL REPORTING INDEX SEBAGAI INDIKATOR AKUNTABILITAS SOSIAL BANK SYARIAH
}

\author{
Muhammad Taufiq Abadi 1), Muhammad Sultan Mubarok ${ }^{2)}$, Ria Anisatus \\ Sholihah ${ }^{3)}$ \\ ${ }^{1,2,3)}$ Fakultas Ekonomi Dan Bisnis IAIN Pekalongan
}

Jl. Pahlawan, Rowolaku, Kajen, Kabupaten Pekalongan, Jawa Tengah 51161;

Bojong, Jawa Tengah, Indonesia 51161

muhammad.taufiq.abadi@iainpekalongan.ac.id ${ }^{1)}$,

muhammad.sultan.mubarok@iainpekalongan.ac.id ${ }^{2)}$, ria.anisatus.sholihah@iainpekalongan.ac.id ${ }^{3)}$

\begin{abstract}
ABSTRAK
Penelitian ini membahas tentang definisi Islamic social reporting index, kerangka Syariah ISR, tema pengungkapan ISR, dan implementasi ISR index sebagai akuntabilitas aktivitas sosial bank Syariah. Penelitian ini menggunakan pendekatan kualitatif, jenis penelitian kepustakaan dengan analisis isi (content analysis) sebagai alat analisis data. Hasil penelitian menyimpulkan bahwa, Pertama tema pendanaan dan investasi terdapat 6 BUS yang kurang informatif, kedua pada tema produk dan jasa yang kurang informatif adalah BRI Sy, ketiga pada tema karyawan terdapat 5 BUS yang kurang informatif, keempat pada tema Masyarakat terdapat 6 BUS yang kurang informatif, , kelima pada tema lingkungan terdapat 9 BUS yang kurang informatif. Walaupun sebenarnya skor indeks ISR yang rendah (kurang informatif) tidak dapat diartikan bahwa perusahaan tersebut tidak melakukan pengungkapan tanggung jawab sosial secara syariah dengan baik karena terdapat dua kemungkinan, yaitu perusahaan tersebut melakukan tanggung jawab sosial secara syariah akan tetapi tidak diungkapkan dalam laporan-laporannya atau perusahaan tersebut memang tidak melakukan tanggung jawab sosial secara Syariah.
\end{abstract}

Kata Kunci: Islamic Social Reporting, ISR BUS, ISR Bank Syariah 


\begin{abstract}
This study discusses the definition of the Islamic social reporting index, the ISR Sharia framework, the theme of ISR disclosure, and the implementation of the ISR index as accountability for Sharia bank social activities. This study uses a qualitative approach, a type of library research with content analysis as a data analysis tool. The results of the study concluded that, First the theme of funding and investment there are 6 BUS which are less informative, second on the theme of products and services that are less informative is BRI Sy, third on the theme of employees there are 5 BUS which are less informative, fourth on the theme of the Community there are 6 BUS which are less informative, fifth on the environmental theme there are 9 BUS which are less informative. Even though the ISR index score is low (less informative) it cannot be interpreted that the company did not disclose sharia social responsibility properly because there were two possibilities, namely the company carried out sharia social responsibility but was not disclosed in its reports or the company did not carry out social responsibility in a Sharia manner.
\end{abstract}

\title{
Keyword: Islamic Social Reporting, ISR BUS, ISR Bank Syariah
}

\section{PENDAHULUAN}

Islamic Social Reporting (ISR) ${ }^{1}$ menjadi topik yang menarik untuk diperbincangkan dalam kajian akuntansi syariah karena sejauh ini pengukuran CSR disclosure pada lembaga syariah kebanyakan masih mengacu kepada Global Reporting Initiative Index (Indeks GRI) ${ }^{2}$. Indeks ini menjadi acuan semua jenis perusahaan diberbagai negara tanpa memandang aspek syariah atau non syariah. ${ }^{3}$ Padahal secara prinsip dan falsafah aktivitas sosial pada entitas bisnis syariah memiliki perbedaan dengan bisnis non syariah. ${ }^{4}$ Sehingga kehadiran konsep ISR menjadi kebutuhan mengenai pengungkapan aktivitas sosial pada entitas bisnis syariah. ${ }^{5}$

\footnotetext{
${ }^{1}$ Islamic Social Reporting (ISR) adalah sebuah konsep akuntabilitas berbasis syariah yang bertujuan untuk memberikan pengungkapan penuh dalam konteks Islam. Lihat pada Othman, Rohana, Azlan Md Thani dan erlane K Ghani, "Determints of islamic social reporting Among Top shariah-approved Comapnies in Bursa malaysia" (Research Journal of International Studies Issue 12 oktober, 2009) h. 5

${ }^{2}$ Global Reporting Initiative Index (Indeks GRI) adalah sebuah organisasi yang menyediakan kerangka kerja untuk pelaporan keberlanjutan yang dapat diadopsi oleh semua jenis organisasi disemua negara, GRI ini dibentuk oleh organisasi Amerika Serikat yang berbasis nirlaba Yaitu Coalition For Environmentally Responsible Economies (CERES) dan Tellus Institute dengan dukungan United Nations Environment Programme (UNEP) pada tahun 1997.

3 Haniffa, R.,"Social Reporting Disclosure : An Islamic Perspective", (Indonesian Management and Accounting Research, 2002) h. 130

${ }^{4}$ M. yasir yusuf, islamic social reporting (I-CSR) pada lembaga keuangan syariah: teori dan praktik, (depok: kencana, 2017), h. 56-57

${ }^{5}$ Othman, Rohana, Azlan Md Thani dan erlane K Ghani, "Determints of islamic social reporting Among Top shariah-approved Comapnies in Bursa malaysia" (Research Journal of International Studies Issue 12 oktober, 2009) h. 5
} 
Di Indonesia, Pengungkapan (dislosure) pada bank syariah ini secara umum telah terakomodasi dalam Pernyataan Standar Akuntansi Keuangan. Yakni PSAK No. 101 tahun 2006 tentang penyajian laporan keuangan syariah. Namun PSAK ini hanya berlaku untuk laporan keuangan dan tidak berlaku untuk informasi lain yang disajikan dalam laporan tahunan. ${ }^{6}$ Sehingga terdapat variasi, karena belum adanya standar khusus yang dapat dijadikan pedoman bagi keseragaman penyajian laporan tersebut, baik dari tema yang diungkapkan, tingkat pengungkapan, lokasi atau tempat pengungkapan dalam laporan tahunan dan tipe pengungkapan. Hal inilah yang memicu pemikiran tentang ISR.

Dari awal tercetusnya ISR diharapkan melahirkan konsep dan praktik akuntansi yang sesuai dengan syariat Islam. Instrumen tersebut memberikan kontribusi kepada kemajuan bisnis yang lebih jujur dan adil. Oleh karena itu dengan mempersiapkan konsep akuntabilitas sosial akan mendorong terpenuhinya kebutuhan publik atas suatu informasi berdasarkan prinsip-prinsip syariah. Konsep akuntabilitas sosial bertujuan untuk memenuhi kebutuhan publik akan suatu informasi. Dalam konteks Islam, masyarakat mempunyai hak untuk mengetahui berbagai informasi mengenai aktivitas organisasi. Hal ini dilakukan untuk melihat apakah perusahaan tetap melakukan kegiatannya sesuai syariah dan mencapai tujuan yang telah ditetapkan. Salah satu cara untuk memberikan pengungkapan penuh dalam konteks Islam yaitu dengan penerapan ISR. ${ }^{7}$

ISR pertama kali dikemukakan oleh $\mathrm{Haniffa}^{8}$, kemudian dikembangkan secara ekstensif oleh Othman et al., ${ }^{9}$ secara spesifik di Malaysia. Menurut Haniffa terdapat keterbatasan dalam laporan sosial konvensional sehingga ia mengemukakan sebuah kerangka konseptual ISR yang berdasarkan ketentuan syariah Islam. Kerangka konseptual ini tidak hanya membantu para pengambil keputusan muslim, tetapi juga membantu perusahaan dalam menjalankan aktivitas dan pelaporan yang sesuai ketentuan syariah. Hal ini dilakukan dalam rangka pemenuhan kewajiban terhadap Allah Swt. dan masyarakat sekitarnya. ${ }^{10}$

Selanjutnya berkembangnya ISR turut meningkatkan perhatian masyarakat terhadap lembaga atau institusi syariah. Hal tersebut dikarenakan adanya kebutuhan masyarakat untuk mengenal secara lebih dalam terhadap lembaga atau institusi syariah. ${ }^{11}$ Bank Syariah sebagai instrumen lembaga keuangan syariah memiliki

\footnotetext{
${ }^{6}$ Pernyataan Standar Akuntansi Keuangan (PSAK) No. 101 tahun 2007 tentang penyajian laporan keuangan syariah. h. 101.12. https:// abufadilah. files. wordpress. com/2011/07/psak-101.pdf

${ }^{7}$ Othman, Rohana, Azlan Md Thani dan erlane K Ghani, "Determints of Islamic Social Reporting... h. 5

8Haniffa, R.,"Social Reporting Disclosure : An Islamic Perspective.. h. 129

${ }^{9}$ Othman, Rohana, Azlan Md Thani dan erlane K Ghani, "Determints of Islamic Social Reporting... h. 2

10Haniffa, R.,"Social Reporting Disclosure : An Islamic Perspective.. h. 132

${ }^{11}$ Bayu Tri Cahya, "Islamic Social Reporting: Ditinjau dari Aspek Corporate Governance Strength, Media Exposure dan Karakteristik Perusahaan Berbasis Syariah di Indonesia Serta Dampaknya Terhadap Nilai Perusahaan" (Disertasi, Universitas Islam Negeri Sumatera Utara Medan, 2017), h. 8 .http://repository.uinsu.ac.id/2115/1/DISERTASI\%20BAYU\%20TRI\%20CAHYA\%2093314050520.pdf
} 
peran penting dalam peta perekonomian nasional. Secara makro ekonomi dapat merekatkan hubungan antara sektor keuangan dengan sektor riil serta menciptakan harmonisasi di antara kedua sektor tersebut. Karakteristik sistem perbankan syariah yang beroperasi berdasarkan prinsip bagi hasil memberikan alternatif sistem perbankan yang saling menguntungkan bagi masyarakat dan bank. Serta menonjolkan aspek keadilan dalam bertransaksi, investasi yang beretika, mengedepankan nilai-nilai kebersamaan, persaudaraan dalam berproduksi, dan menghindari kegiatan spekulatif dalam bertransaksi. ${ }^{12}$

Hingga saat ini tingkat pengungkapan ISR Bank Umum Syariah (BUS) di Indonesia masih rendah, hal ini sesuai dengan penelitian Trisnawati ${ }^{13}$, Lukman dan Zaki $^{14}$ yang menyimpulkan BUS di Indonesia kurang informatif (dengan skor dibawah 50\%) dalam pengungkapan ISR. Bahkan tingkat pengungkapan ISR Malaysia lebih baik dibandingkan di Indonesia hasil riset Hafiez Sofyani dkk., ${ }^{15}$ dan Hafiez dan Setiawan. ${ }^{16}$ Hasil penelitian terdahulu ini menjadi dasar peneliti untuk mengkaji lebih lanjut tentang tingkat pengungkapan aktivitas sosial bank Syariah dengan indeks ISR.

Untuk mengetahui secara luas tentang tema tersebut, penulis berusaha mengumpulkan karya-karya yang relevan, baik berupa buku, artikel, jurnal, tesis atau disertasi. Diantara karya-karya yang berkontinu yaitu 1) ${ }^{\text {Haniffa }}$, R., dengan judul "Social Reporting Disclosure: An Islamic Perspective" 17, 2) Othman et al., "Determints of islamic social reporting Among Top shariah-approved Comapnies in Bursa Malaysia"18. 3) Sayd Farook et al., .dengan judul "Determinants of corporate social responsibility disclosure: the case of Islamic banks"19 4) Rania dan Hussain dengan judul "Social reporting by Islamic banks: does social justice

12 Bank Indonesia, "Sekilas Perbankan Syariah di Indonesia" diakses pada 14 Maret 2018, https://www.bi.go.id/id /perbankan /syariah/ Contents /Default .aspx

${ }^{13}$ Arif Lukman Santosoa, Zaki Murtadho Dhiyaul-Haq, "Determin Pengungkapan Islamic Social Reporting pada Bank umum Syariah di Indonesia” (2017) Junal Dinamika Akuntansi dan Bisnis (JDAB) Vol. 4(2), 2017, pp 125-142. Diakses 21 november 2017 https://doi.org/ 10.24815/JDAB.V412.6421

${ }^{14}$ Arif Lukman Santosoa, Zaki Murtadho Dhiyaul-Haq, "Determin Pengungkapan Islamic Social Reporting pada Bank umum Syariah di Indonesia” (2017) Junal Dinamika Akuntansi dan Bisnis (JDAB) Vol. 4(2), 2017, pp 125-142. Diakses 21 november 2017 https://doi.org/ 10.24815/JDAB.V412.6421

${ }^{15}$ Hafiez Sofyani, Ihyaul Ulum, Daniel Syam dan Sri Wahjuni L, "Islamic Social Reporting Index Sebagai Model Pengukuran Kinerja Sosial Perbankan Syariah (Studi Komparasi Indonesia Dan Malaysia)" (2012) JDA: Jurnal Dinamika Akuntansi Vol. 4, No. 1, Maret 2012, pp.36-46. ISSN 2085-4277 diakses 20 november 2017. http://journal.unnes.ac.id/index.php/jda

${ }^{16}$ Hafiez Sofyani dan Anggar Setiawan, "Perbankan Syariah Dan Tanggungjawab Sosial:Sebuah Studi Komparasi Indonesia Dan Malaysia Dengan Pendekatan Islamic Social Reporting Index Dan Global Reporting Initiative Index" (2011), JDA: Jurnal Dinamika Akuntansi Vol. 4, No. 1, Maret 2012, pp.36-46. ISSN 2085-4277 diakses 20 november 2017. http://journal.unnes.ac.id/index.php/jda

17 Haniffa, R.,"Social Reporting Disclosure : An Islamic Perspective", ( Indonesian Management and Accounting Research, 2002) h. 130

${ }^{18}$ Othman, Rohana, Azlan Md Thani dan erlane K Ghani, "Determints of islamic social reporting Among Top shariah-approved Comapnies in Bursa malaysia" (Research Journal of International Studies Issue 12 oktober, 2009) h. 5

${ }^{19}$ Sayd Farook, M. Kabir Hassan, Roman Lanis, "Determinants of corporate social responsibility disclosure: the case of Islamic banks", (Journal of Islamic Accounting and Business Research, 2011) Vol. 2 Issue: 2, pp.114141, https://doi.org/10.1108/17590811111170539 
matter?"20. 6) Haniffa, R. \& Hudaib, dengan judul ," Exploring the Ethical Identity of Islamic Banks via Communication in Annual Reports",21,7) Zakaria dan Simon dengan judul "Narrative disclosure of corporate social responsibility in Islamic financial institutions" 22

Penelitian ini memiliki kesamaan metode maupun teori dengan beberapa penelitian terdahulu diatas, yakni teori tentang Islamic Social Reporting (ISR) yang mengadopsi konsep Haniffa, Othman, Haniffa dan Hudaib, dan Gustani, kemudain menambhakan beberapa item sesuai standar aturan Bank Indonesia dan Otoritas Jasa Keuangan, sehingga didapat 70 sub item yang digunakan untuk mengukur kinerja sosial bank umum syariah. Akan tetapi penelitian ini memiliki titik Perbedaan dengan penelitian sebelumnya, yakni pada periode penelitian, penelitian ini akan difokuskan pada tingkat pengungkapan ISR pada BUS dengan periode 2013-2017.

Penelitian ini menggunakan penelitian kepustakaan (library research) dengan pendekatan deskriptif. Yaitu dengan mendeskripsikan atau menjelaskan ISR pada BUS di Indonesia. Metode pengumpulan data pada penelitian ini menggunakan metode dokumentasi, kemudian dianalisis menggunakan content analysis (analisis isi), yaitu dengan menganalisa data-data kepustakaan yang bersifat deskriptif.

\section{DEFINISI DAN KERANGKA SYARIAH ISLAMIC SOCIAL REPORTING (ISR)}

\section{A. Definisi Islamic Social Reporting (ISR)}

Islamic Social Reporting (ISR) merupakan Salah satu cara utuk menilai pelaporan tanggung jawab sosial perusahaan secara syariah. Menurut Haniffa ISR adalah perpanjangan pelaporan sosial yang meliputi tidak hanya harapan dewan pengurus atas pandangan masyarakat terhadap peran perasaan dalam ekonomi tetapi juga pemenuhan perspektif spiritual untuk pengguna laporan yang muslim. ISR memiliki dua tujuan utama, yang pertama sebagai akuntabilitas kepada Allah SWT dan komunitas dan yang kedua yaitu untuk meningkatkan transparansi kegiatan bisnis dengan cara memberikan informasi yang relevan dan sesuai dengan kebutuhan spiritual para pembuat keputusan muslim. Selain itu indeks ISR juga

\footnotetext{
${ }^{20}$ Rania Kamla, Hussain G. Rammal, "Social reporting by Islamic banks: does social justice matter?", (Accounting, Auditing \& Accountability Journal, 2013), Vol. 26 Issue: 6, pp.911-945, https://doi.org/10.1108/AAAJ-03-2013-1268

${ }^{21}$ Haniffa, R. \& Hudaib, M. J Bus Ethics,” Exploring the Ethical Identity of Islamic Banks via Communication in Annual Reports", (Journal of Business Ethics, 2007, 2007) Volume 76, Number 1, Page 97. https://doi.org/10. 1007/ s10551-006-9272-5

${ }^{22}$ Zakaria Ali Aribi, Simon S. Gao, "Narrative disclosure of corporate social responsibility in Islamic financial institutions", (Managerial Auditing Journal, 2011), Vol. 27 Issue: 2, pp.199-222, https://doi.org/10. 1108/ $\underline{02686901211189862}$
} 
menekankan pada keadilan sosial terkait pelaporan mengenai lingkungan, kepentingan minoritas dan karyawan. ${ }^{23}$

Menurut Bayu Tri Cahya ISR adalah pelaporan sosial yang tidak hanya melibatkan harapan secara holistik dari masyarakat mengenai peran perusahannya tetapi juga pada perspektif spiritual. ${ }^{24}$ Menurut Soraya Fitria dan Dwi Hartanti, Indeks ISR adalah indeks yang berisi item-item standard CSR yang ditetapkan oleh AAOIFI (Accounting and Auditing Organization for Islamic Financial Institutions) yang kemudian dikembangkan lebih lanjut oleh peneliti-peneliti mengenai itemitem CSR yang seharusnya diungkapkan oleh suatu entitas Islam. ${ }^{25}$

ISR adalah standar pelaporan kinerja sosial perusahaan-perusahaan yang berbasis syariah. Indeks ini lahir dikembangkan dengan dasar dari standar pelaporan berdasarkan AAOIFI yang kemudian dikembangkan oleh Haniffa membuat lima tema pengungkapan Indeks ISR, yaitu Tema Pendanaan dan Investasi, Tema Produk dan Jasa, Tema Karyawan, Tema Masyarakat, dan Tema Lingkungan Hidup. Kemudian dikembangkan oleh Othman et al dengan menambahkan satu tema pengungkapan yaitu tema Tata Kelola Perusahaan. Setiap tema pengungkapan memiliki sub-tema sebagai indikator pengungkapan tema tersebut. Beberapa peneliti Indeks ISR sebelumnya memiliki perbedaan dalam hal jumlah sub-tema yang digunakan, tergantung objek penelitian yang digunakan. ${ }^{26}$

Prinsip syariah sebagai landasan dasar dalam ISR menghasilkan aspekaspek material, moral, dan spiritual yang menjadi fokus utama dari pelaporan sosial perusahaan. ${ }^{27}$ Menurut Baydoun dan willet dalam Fahri Ali Ahzar dan Rina Trisnawati, terdapat dua hal yang harus diungkapkan dalam perspektif Islam, pertama pengungkapan penuh (full disclosure) dan akuntabilitas sosial (Social accountability), Konsep akuntabilitas sosial terkait dengan prinsip pengungkapan penuh dengan tujuan untuk memenuhi kebutuhan publik akan suatu informasi. Dalam konteks Islam, masyarakat mempunyai hak untuk mengetahui berbagai informasi mengenai aktivitas organisasi. Hal ini dilakukan untuk melihat apakah

23Haniffa, R.,"Social Reporting Disclosure : An Islamic Perspective”, ( Indonesian Management and Accounting Research, 2002) 128-146. https://www.scribd.com/doc/312550684/Haniffa-R-Social-Reporting-Disclosure-AnIslamic-Perspective-2002

${ }^{24}$ Bayu Tri Cahya, “Islamic Social Reporting: Ditinjau Dari Aspek Corporate Governance Strength, Media Exposure dan Karakteristik Perusahaan Berbasis Syariah di Indonesia Serta Dampaknya Terhadap Nilai Perusahaan"( Disertasi, Universitas Islam Negeri Sumatera Utara Medan, 2017), i .http://repository.uinsu.ac.id/2115/1/DISERTASI\%20BAYU\%20TRI\%20CAHYA\%2093314050520.pdf

${ }^{25}$ Soraya Fitria dan Dwi Hartanti, "Islam Dan Tanggung Jawab Sosial : Studi Perbandingan Pengungkapan Berdasarkan Global Reporting Initiative Indeks Dan Islamic Social Reporting Indeks". (Simposium Nasional Akuntansi XIII, Purwokerto, 2010), 4.

${ }^{26}$ Othman, Rohana, Azlan Md Thani dan erlane K Ghani, "Determints of islamic social reporting Among Top shariah-approved Comapnies in Bursa malaysia” (Research Journal of International Studies Issue 12 oktober, 2009)

${ }^{27}$ Saiful Muchlis dan Rizki Auliah, "Implementasi islamic social reporting dalam Pengembangan Pembiayaan Koperasi Syariah BTM AL-KAUTSAR”, (Jurnal Akuntansi Multiparadigma, Volume 7, Nomor 1, April 2016), 272 . 
perusahaan tetap melakukan kegiatannya sesuai syariah dan mencapai tujuan yang telah ditetapkan. ${ }^{28}$

\section{B. Kerangka Syariah Islamic Social Reporting (ISR)}

Kerangka syariah ISR mulai dikenalkan pertama kali oleh Ross Haniffa ${ }^{29}$, dan kemudian dikembangkan lebih lanjut oleh Rohana Othman, Azlan Md Thani, dan Erlane K Ghani ${ }^{30}$ di Malaysia dan saat ini masih terus dikembangkan oleh penelitipeneliti selanjutnya. Menurut Haniffa terdapat banyak keterbatasan dalam pelaporan sosial konvensional, sehingga dirumuskan kerangka konseptual ISR yang berdasarkan ketentuan syariah. ISR ini tidak hanya membantu pengambil keputusan bagi pihak muslim melainkan juga untuk membantu perusahaan dalam melakukan pemenuhan kewajiban terhadap Allah dan masyarakat menjadi landasan dasar atas terbentuknya ISR yang komprehensif. Kerangka syariah ini akan menghasilkan aspek-aspek material, moral, dan spiritual dalam pelaporan ISR perusahaan. ${ }^{31}$ Berikut Kerangka ISR menurut Ross Haniffa:

\section{Gambar 1.1}

\section{Kerangka Syariah ISR menurut Ross Haniffa ${ }^{32}$}

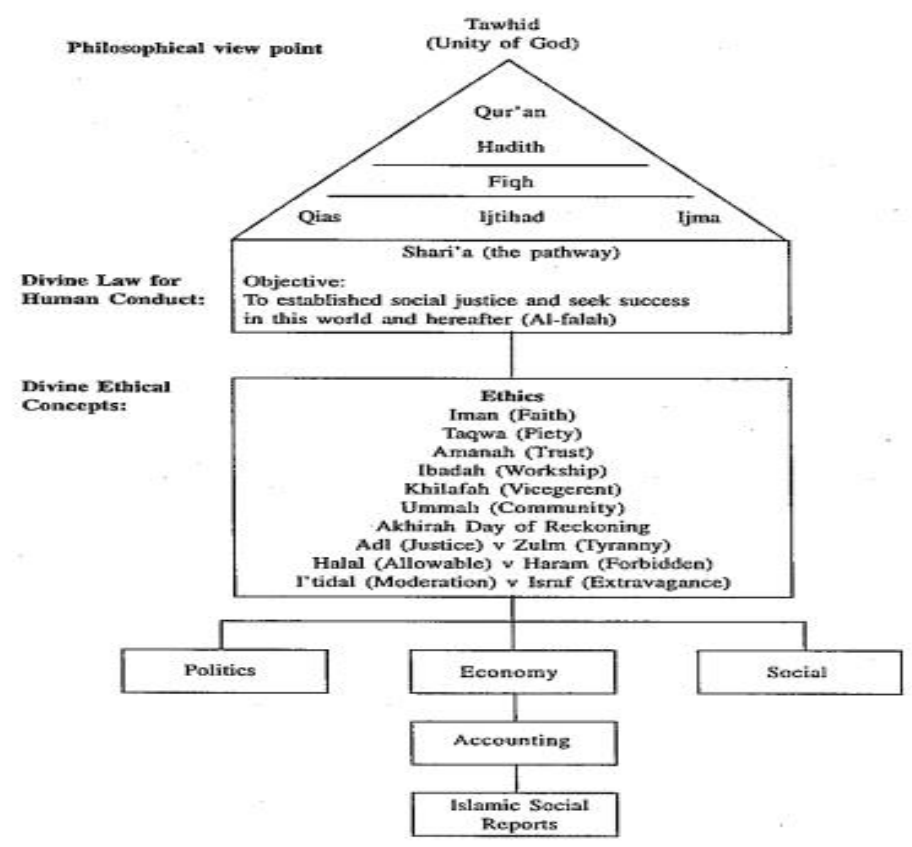

(Sumber: Haniffa, 2002, data diolah 2018)

\footnotetext{
${ }^{28}$ Fahri Ali Ahzar dan Rina Trisnawati, "pengungkapan islamic social reporting pada bank syariah di Indonesia", ()

29 Haniffa, R., "Social Reporting Disclosure : An Islamic Perspective”... h. 128

${ }^{30}$ Othman, Rohana, Azlan Md Thani dan erlane K Ghani, "Determints of islamic social reporting"...

31 Haniffa , R.,"Social Reporting Disclosure : An Islamic Perspective"... h. 128

32 Haniffa, R., "Social Reporting Disclosure : An Islamic Perspective"... h. 128
} 
Tauhid dalam kerangka syariah merupakan pondasi dari ajaran Islam. Secara bahasa, tauhid berasal dari kata Ahad, yang artinya satu, tunggal, esa. Sedang secara istilah tauhid memiliki makna yakin bahwa Allah Swt., adalah esa dan tidak ada sekutu bagi-Nya dalam rububiyah (ketuhanan), uluhiyah (Ibadah), asma" (namanama), dan sifat-sifat-Nya. Dengan tauhid menunjukkan bahwa alam semesta ini satu dan bahwa kesatuan seluruh isi dan tatanannya ekonomi, politik, sosial, maupun lingkungan di alam semesta ini diikat oleh sebuah inti. Inti itu adalah Tauhid (Q.S. Thaha/20: 53-54) ${ }^{33}$

Wujud dari tauhid adalah syahadat. Syahadat yaitu pengakuan akan keesaan Allah Swt., yang diyakini dalam hati, dibenarkan dengan lisannya, dan dibuktikan dengan amal perbuatan nyata. Syahadat menjadi salah satu rukun Islam dan merupakan syarat utama seseorang masuk agama Islam. Orang yang mengucapkan syahadat akan menerima konsekwensi dari tauhid berupa kewajiban untuk tunduk terhadap segala hukum Allah Swt., yang bersumber dari Alquran, Hadis, fikih, dan sumber lainya seperti Qias, Ijtihad, dan Ijma. Tujuan dari hukum syariah ini adalah untuk menegakkan keadilan sosial dan mencapai kebahagiaan di dunia dan di akhirat (al falah). ${ }^{34}$

Kemudian hukum syariah ini akan menjadi dasar terbentuknya konsep etika dalam Islam. Secara umum, etika dalam Islam terdiri dari sepuluh etika yang mengatur hubungan manusia dengan Allah Swt., manusia dengan manusia, dan manusia dengan alam semesta. Kesepuluh konsep etika tersebut adalah iman (faith), taqwa (piety), amanah (trust), ibadah (workship), khilafah (vicegerent), ummah (community), keyakinan akan datangnya hari kiamat (akhirah day of reckoning), adl (justice) dan zulm (tyrnny), halal (allowable) dan haram (forbidden), serta I'tidal (moderation) dan israf (extravagance). Etika ini akan menjadi landasan manusia dalam melakukan aktivitas politik, ekonomi, dan sosial. ISR berada pada lingkup aktivitas ekonomi, khususnya aspek akuntansi. Dengan demikian, ISR merupakan bagian dari kerangka syariah. ${ }^{35}$

Al-Qur'an menitik beratkan akuntansi pada surat Al-Baqarah ayat 282 yang menjelaskan fungsi-fungsi pencatatan (kitabah), dasar dan manfaatnya.

"Hai orang-orang yang beriman, jika kamu bermuamalah tidak secara tunai sampai waktu tertentu, buatlah secara tertulis........"

Ayat di atas juga menjelaskan tentang prinsip akuntansi syariah secara umum yang terdiri dari: pertama prinsip pertanggungjawaban, implikasi dalam bisnis dan

33 Haniffa, R., dalam Bayu Tri Cahya, "Islamic Social Reporting: Ditinjau Dari Aspek Corporate Governance Strength, Media Exposure... h. 106

34 Haniffa , R., dalam Bayu Tri Cahya, "Islamic Social Reporting: Ditinjau Dari Aspek Corporate Governance Strength, Media Exposure... h. 107

35Haniffa, R., dalam Bayu Tri Cahya, "Islamic Social Reporting: Ditinjau Dari Aspek Corporate Governance Strength, Media Exposure... h. 108 
akuntansi adalah bahwa individu yang terlibat dalam praktik bisnis harus selalu melakukan pertanggung jawaban apa yang telah diamanatkan dan diperbuat kepada pihak-pihak yang terkait dan biasanya dalam bentuk laporan akuntansi, kedua prinsip keadilan, berkaitan dengan praktik moral, yang merupakan faktor yang sangat dominan dan bersifat lebih fundamental (dan tetap berpijak pada nilai-nilai etika/syariah dan moral), ketiga prinsip kebenaran, Kebenaran di dalam Al-Qur'an tidak diperbolehkan untuk dicampuradukkan dengan kebathilan. Al-Qur'an telah menggariskan, bahwa ukuran, alat atau instrument untuk menetapkan kebenaran tidaklah didasarkan pada nafsu. ${ }^{36}$

\section{Tabel 1.2}

\section{Tujuan, Bentuk Akuntabilitas dan Transparansi dalam ISR ${ }^{37}$}

Tujuan dari ISR yaitu sebagai berikut:

1. Sebagai bentuk akuntabilitas kepada Allah SWT dan masyarakat.

2. Meningkatkan transparansi kegiatan bisnis dengan menyajikan informasi yang relevan dengan memperhatikan kebutuhan spiritual investor muslim atau kepatuhan syariah dalam pengambilan keputusan.

\begin{tabular}{l|l}
\hline \multicolumn{1}{c|}{ Bentuk Akuntabilitas } & \multicolumn{1}{c}{ Bentuk Transparansi } \\
\hline 1. Menyediakan produk yang halal dan baik & $\begin{array}{l}\text { 1.Memberikan informasi } \\
\text { mengenai } \\
\text { semua kegiatan yang halal dan } \\
\text { haram }\end{array}$ \\
\hline $\begin{array}{l}\text { 2. Memenuhi hak-hak Allah dan } \\
\text { masyarakat }\end{array}$ & $\begin{array}{l}\text { 2. Memberikan informasi yang } \\
\text { relevan mengenai pembiayaan } \\
\text { dan kebijakan investasi }\end{array}$ \\
\hline $\begin{array}{l}\text { 3. Mengejar keuntungan yang wajar sesuai } \\
\text { dengan prinsip Islam }\end{array}$ & $\begin{array}{l}\text { 3. Memberikan informasi yang } \\
\text { relevan mengenai kebijakan } \\
\text { karyawan }\end{array}$ \\
\hline 4. Mencapai tujuan usaha bisnis & $\begin{array}{l}\text { 4. Memberikan informasi yang } \\
\text { relevan mengenai hubungan } \\
\text { dengan masyarakat }\end{array}$ \\
\hline 5. Menjadi karyawan dan masyarakat & $\begin{array}{l}\text { 5. Memberikan informasi yang } \\
\text { relevan mengenai penggunaan } \\
\text { sumber daya dan perlindungan } \\
\text { lingkungan }\end{array}$ \\
\hline $\begin{array}{l}\text { 6. Memastikan kegiatan usaha yang } \\
\text { berkelanjutan secara ekologis }\end{array}$ & \\
\hline
\end{tabular}

\footnotetext{
${ }^{36}$ Ali Mauludi AC, "Akuntansi Syariah: pendekatan normatif, historis dan aplikatif, ( Jurnal Iqtishadia Vol. 1, No. 1, 2014) H. 62

37 Haniffa, R.,"Social Reporting Disclosure : An Islamic Perspective”... h. 136
} 


\section{Menjadikan pekerjaan sebagai bentuk} ibadah

(Sumber: Haniffa (2002), data diolah)

\section{TEMA PENGUNGKAPAN ISLAMIC SOCIAL REPORTING (ISR)}

Indeks ISR adalah item-item pengungkapan yang digunakan sebagai indikator dalam pelaporan kinerja sosial institusi bisnis syariah. ${ }^{38}$ Haniffa mengembangkan lingkup pengungkapan ISR yang dibatasi dalam 5 tema, yaitu: keuangan dan investasi, produk, karyawan, masyarakat dan lingkungan. ${ }^{39}$ Othman et al. mengembangkan instrumen indeks milik Hanifa menjadi 43 item indeks pengungkapan, dengan menambahkan tema tata kelola perusahaan yang dianggap penting karena dapat memastikan apakah perusahaan mematuhi prinsip-prinsip syariah dan tidak melakukan aktivitas/transaksi yang melanggar prinsip-prinsip syariah. ${ }^{40}$

Setiap tema pengungkapan memiliki sub-tema sebagai indikator pengungkapan tema tersebut. Jumlah sub-tema yang dijadikan indikator memiliki perbedaan pada beberapa penelitian terdahulu, hal ini tergantung dari objek dan lokasi penelitian yang digunakan peneliti. Haniffa menggunakan 14 sub tema ISR, Othman et al menggunakan 43 sub tema ISR, Haniffa dan Hudaib menambahkan beberapa sub tema ISR $^{41}$, sedangkan riset yang dilakukan oleh Gustni ${ }^{42}$ dan Rika Hayati ${ }^{43}$ menggabungkan sub tema dari beberapa peneliti terdahulu dan menambahkan beberapa peraturan yang berlaku di Indonesia yang merujuk pada surat edaran bank Indonesia (SEBI) sehingga didapat 53 sub tema pengungkapan ISR. Penelitian ini menggunakan 53 sub tema yang digunakan oleh Gustani dan Rika Hayati, berikut ini disajikan rincian indeks ISR sebagai berikut:

\section{1) Pendanaan dan Investasi (Finance \& Investment)}

Konsep dasar pada tema ini adalah tauhid, halal, haram dan wajib beberapa informasi yang diungkapkan pada tema ini menurut Haniffa adalah praktik operasional yang mengandung riba gharar, dan aktivitas pengelolaan zakat. Salah satu bentuk riba di dunia perbankan adalah pendapatan dan beban bunga. ${ }^{44}$ Kegiatan yang mengandung gharar pun merupakan yang terlarang dalam Islam. Gharar

\footnotetext{
${ }^{38}$ Bayu Tri Cahya, "Islamic Social Reporting.. h. 109

39Haniffa, R. (2002). Social Reporting Disclosure...... Hlm. 128-146

${ }^{40}$ Othman, Rohana, Azlan Md Thani dan erlane K Ghani, "Determints of islamic social...

${ }^{41}$ Haniffa dan Hudaib

${ }^{42}$ Gustani, "Model pelaporan kinerja sosial perbankan syariah: implementasi islamic social reporting index (indeks ISR) di Indonesia", (Jurnal Akuntansi dan Keuangan Islam 1, No. 2, 2013), h. 38

${ }^{43}$ Rika Hayati, "Analisis pengaruh shari'a governance structure terhadap pengungkapan corporate social resbonsibility pada perbankan syariah di Indonesia tahun 2011-2015”, (Skripsi, Universitas Islam Negeri Jakarta, 2016), h. 56-58

44 Haniffa, R., "Social Reporting Disclosure : An Islamic Perspective”... h. 137
} 
adalah situasi dimana terjadi incomplete information karena adanya uncertainty to both parties. Praktik gharar dapat terjadi dalam empat hal, yaitu kuantitas, kualitas, harga, dan waktu penyerahan. Contoh transaksi modern yang mengandung riba adalah transaksi lease and purchase, karena adanya ketidak jelasan antara transaksi sewa atau beli yang berlaku. ${ }^{45}$

Gharar atau taghrir berarti risiko atau ketidakpastian. Dalam pengertian fikih taghrir berarti melakukan segala sesuatu tanpa pengetahuan yang mencukupi atau mengambil risiko sendiri dari suatu perbuatan yang mengandung risiko tanpa mengetahui secara pasti akibatnya. ${ }^{46}$ Bentuk lain dari gharar adalah future on delivery trading atau margin trading,. jual-beli valuta asing bukan transaksi komersial (arbitage baik spot maupun forward, melakukan penjualan melebihi jumlah yang dimiliki atau dibeli (short selling), melakukan transaksi pure swap, capital lease, future, warrant, Option, dan transaksi derivatif lainnya. ${ }^{47}$

Aspek lain yang harus diungkapkan oleh entitas syariah adalah praktik pembayaran dan pengelolaan zakat. Entitas syariah berkewajiban untuk mengeluarkan zakat dari laba yang diperoleh, dalam fiqh kontemporer di kenal dengan istilah zakat perusahaan. Berdasarkan AAOIFI, perhitungan zakat bagi entitas syariah dapat menggunakan dua metode. Metode pertama, dasar perhitungan zakat perusahaan dengan menggunakan metode net worth (kekayaan bersih). Artinya seluruh kekayaan perusahaan, termasuk modal dan keuntungan harus dihitung sebagai sumber yang harus dizakatkan. Metode kedua, dasar perhitungan zakat adalah keuntungan dalam setahun. ${ }^{48}$ Selain itu bagi bank syariah berkewajiban untuk. melaporkan laporan sumber dan penggunaan dana zakat selama periode dalam laporan keuangan. Bahkan jika bank syariah belum melakukan fungsi zakat secara penuh, bank syariah tetap menyajikan laporan zakat. ${ }^{49}$

Pengungkapan selanjutnya yang merupakan penambahan dari Othman et al adalah kebijakan atas keterlambatan pembayaran piutang dan kebangkrutan klien, neraca dengan nilai saat ini (Current Value Balance Sheet), dan laporan nilai tambah (Value added statement). ${ }^{50}$ Terkait dengan kebijakan atas keterlambatan pembayaran piutang dan kebangkrutan klien Untuk meminimalisir resiko pembiayaan, Bank Indonesia mengharuskan bank untuk mencadangkan penghapusan bagi aktiva-aktiva produktif yang mungkin bermasalah, praktik ini disebut pencadangan penghapusan piutang tak tertagih (PPAP).

\footnotetext{
${ }^{45}$ Adiwarman Karim, Bank Islam Analisis Fiqh Dan Keuangan, (Jakarta: PT Grafindo Persada, 2004).

${ }^{46}$ Sulaeman Jajuli, Produk Pendanaan Bank Syariah, (Yogyakarta: Deepublish, 2008) Ed. 1, Cet. 1, h. 48

${ }^{47}$ Zainul Arifin, Dasar-dasar Manjemen Bank Syariah, (Jakarta: Alfabet, 2009),

${ }^{48}$ Abd Atang Hakim, Fiqh Perbankan Syariah: transformasi fiqih muamalah ke dalam peraturan perundangundangan, (Jakarta: Aditama, 2011)

${ }^{49}$ Pernyataan Standar Akuntansi Keuangan (PSAK) No. 101 Tahun 2011, Tentang penyajian laporan keuangan Syariah.

${ }^{50}$ Othman, Rohana, Azlan Md Thani dan erlane K Ghani, “Determints of islamic social reporting... h. 19
} 
Dalam fatwa DSN MUI ditetapkan bahwa pencadangan harus diambil dari dana (modal/keuntungan) bank. Sedang menurut AAOIFI, pencadangan disisihkan dari keuntungan yang diperoleh bank sebelum dibagikan ke nasabah. Ketentuan PPAP bagi bank syariah juga telah diatur dalam PBI No.5 Tahun 2003. Menurut Haniffa dan Hudaib aspek lain yang perlu diungkapkan pada tema ini adalah jenis investasi yang dilakukan oleh bank syariah dan proyek pembiayaan yang dijalankan. Aspek ini cukup diungkapkan secara umum. ${ }^{51}$

\section{2) Produk dan Jasa (Products and Services)}

Menurut Othman et al beberapa aspek yang perlu diungkapkan pada tema ini adalah status kehalalan produk yang digunakan dan pelayanan atas keluhan konsumen. Dalam konteks perbankan syariah, maka status kehalalan produk dan jasa baru yang digunakan adalah melalui opini yang disampaikan oleh DPS untuk setiap produk 'dan jasa baru. ${ }^{52}$

Dewan Pengawas Syariah (DPS) adalah badan yang ada di lembaga keuangan syariah yang bertugas mengawasi pelaksanaan keputusan Dewan Syariah Nasional di lembaga keuangan syariah. ${ }^{53}$ DPS diangkat oleh rapat umum pemegang saham atas rekomendasi Majelis Ulama Indonesia (MUI). DPS wajib dibentuk oleh bank umum syariah dan unit usaha syariah. Produk yang ditawarkan oleh bank syariah tidak boleh menyimpang dari aturan syariah yang telah dituangkan dalam fatwa Dewan Syariah Nasional (DSN). ${ }^{54}$

Selain itu pelayanan atas keluhan nasabah harus juga menjadi prioritas bank syariah dalam rangka menjaga kepercayaan nasabah. Saat ini hampir seluruh bisnis mengedepankan aspek pelayanan bagi konsumen atau nasabah mereka Karena pelayanan yang baik akan berdampak pada tingkat loyalitas nasabah. Hal lain yang harus diungkapkan oleh bank syariah menurut Haniffa dan Hudaib adalah glossary atau definisi setiap produk serta akad yang melandasi produk tersebut. Hal ini mengingat akad-akad di bank syariah menggunakan istilah-istilah yang masih asing bagi masyarakat, sehingga perlu informasi terkait definisi akad-akad tersebut agar mudah dipahami oleh pengguna informasi. ${ }^{55}$

\section{3) Karyawan (Employees)}

Dalam ISR, segala sesuatu yang berkaitan dengan karyawan berasal dari konsep etika amanah dan keadilan. Menurut Haniffa memaparkan bahwa masyarakat Muslim ingin mengetahui apakah karyawan-karyawan perusahaan diperlakukan secara adil dan wajar melalui informasi-informasi yang

\footnotetext{
${ }^{51}$ Haniffa, R. \& Hudaib, M. J Bus Ethics (2007) " Exploring the Ethical Identity of Islamic Banks via Communication in Annual Reports "76: 97. https://doi.org/10.1007/s10551-006-9272-5

${ }_{52}$ Othman, Rohana, Azlan Md Thani dan erlane K Ghani, “Determints of Islamic Social Reporting... h. 19

${ }^{53}$ Ahmad Ifham Sholihin, Pedoman Umum Lembaga Keuangan Syariah, (Jakarta: PT Gremedia Pustaka Utama, 2010) h. 51

${ }^{54}$ Ismail, Perbankan Syariah, (Jakarta: Prenadamedia group, 2011), Edisi. 1, h. 29

${ }^{55}$ Haniffa dan Hudaib, ” Exploring the Ethical Identity of Islamic Banks..., 76: 97.
} 
diungkapkan. ${ }^{56}$ Beberapa informasi. yang berkaitan dengan karyawan menurut Haniffa $^{57}$ diantaranya jam kerja, hari libur, tunjangan untuk karyawan, dan pendidikan dan pelatihan karyawan.

Beberapa aspek lainnya yang ditambahkan oleh Othman et al ${ }^{58}$ adalah kebijakan remunerasi untuk karyawan, kesamaan peluang karir bagi seluruh karyawan baik pria maupun wanita, kesehatan dan keselamatan kerja karyawan, keterlibatan karyawan dalam beberapa kebijakan perusahaan, karyawan dari kelompok khusus seperti cacat fisik atau korban narkoba, tempat ibadah yang memadai, serta waktu atau kegiatan keagamaan untuk karyawan. Selain itu, Haniffa dan Hudaib $^{59}$ juga menambahkan beberapa aspek pengungkapan berupa kesejahteraan karyawan dan jumlah karyawan yang dipekerjakan.

\section{4) Masyarakat (Community Involvement)}

Konsep dasar yang mendasari tema ini adalah Tauhid, ummah, amanah, dan 'adl. ${ }^{60}$ Konsep tersebut menekankan pada pentingnya saling berbagi dan saling meringankan beban masyarakat. Islam menekankan kepada umatnya untuk saling tolong menolong antar sesama. Bentuk saling berbagi dan tolong-menolong bagi bank syariah dapat dilakukan dengan sedekah, wakaf, dan qard. Jumlah dan pihak yang menerima bantuan harus diungkapkan dalam laporan tahunan bank syariah. Hal ini merupakan salah satu fungsi bank syariah yang diamanahkan oleh Syariah dan Undang-Undang. ${ }^{61}$

Beberapa aspek pengungkapan tema masyarakat yang digunakan dalam penelitian ini adalah menurut Haniffa meliputi sedekah, wakaf, dan pinjaman kebajikan. ${ }^{62}$ Sedang beberapa aspek lainnya yang dikembangkan oleh Othman et al diantaranya adalah sukarelawan dari kalangan karyawan, pemberian beasiswa pendidikan, pemberdayaan kerja para lulusan sekolah atau mahasiswa berupa magang, pengembangan generasi muda, peningkatan kualitas hidup bagi masyarakat miskin, kepedulian terhadap anak-anak, kegiatan amal atau sosial, dan dukungan terhadap kegiatan-kegiatan kesehatan, hiburan, olahraga, budaya, pendidikan dan agama. ${ }^{63}$

\section{5) Lingkungan Hidup (Environment)}

Konsep yang mendasari tema ini adalah tauhid, khilafah, mizan, i'tidal, dan akhirah. ${ }^{64}$ Konsep-konsep tersebut menekankan pada prinsip keseimbangan,

\footnotetext{
56 Haniffa , R., "Social Reporting Disclosure : An Islamic Perspective"... h. 137

57 Haniffa, R., "Social Reporting Disclosure : An Islamic Perspective"... h. 137

${ }^{58}$ Othman, Rohana, Azlan Md Thani dan erlane K Ghani, “Determints of islamic social reporting... h. 19

59 Haniffa dan Hudaib, ” Exploring the Ethical Identity of Islamic Banks..., 76: 97.

60 Haniffa, R., "Social Reporting Disclosure : An Islamic Perspective"... h. 137

61 Haniffa, R., "Social Reporting Disclosure : An Islamic Perspective"... h. 138

62 Haniffa, R., "Social Reporting Disclosure : An Islamic Perspective"... h. 137

${ }^{63}$ Othman, Rohana, Azlan Md Thani dan erlane K Ghani, “Determints of islamic social reporting... h. 19

64 Haniffa , R., "Social Reporting Disclosure : An Islamic Perspective”... h. 137
} 
kesederhanaan, dan tanggung jawab dalam menjaga lingkungan. Islam mengajarkan kepada umatnya untuk senantiasa menjaga, memelihara, dan melestarikan bumi. Allah menyediakan bumi dan seluruh isinya termasuk lingkungan adalah untuk manusia kelola tanpa harus merusaknya. Namun watak dasar manusia yang rakus telah merusak lingkungan ini.

Hal ini telah Allah isyaratkan dalam firmannya:

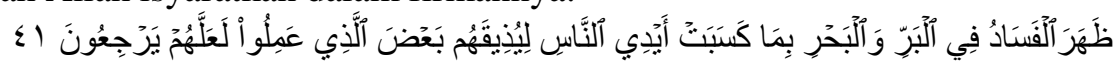

“Telah nampak kerusakan di darat dan di laut disebabkan karena perbuatan tangan manusia, supaya Allah merasakan kepada mereka sebahagian dan (akibat) perbuatan mereka, agar mereka kembali (ke jalan yang benar). " (Q.S Ar Ruum: 41) ${ }^{65}$

Informasi yang diungkapkan dalam tema lingkungan diantaranya adalah menurut Haniffa mencakup penggunaan sumber daya alam dan konservasi lingkungan hidup. ${ }^{66}$ Othman et al menambahkan beberapa sub item yakni tidak membuat polusi lingkungan hidup, pendidikan mengenai lingkungan hidup, dan sistem manajemen lingkungan. ${ }^{67}$ Sedangkan Haniffa dan Hudaib menambahkan sub item yakni penghargaan di bidang lingkungan hidup. ${ }^{68}$

\section{6) Tata Kelola Perusahaan (Corporate Governance)}

Konsep yang mendasari tema ini adalah konsep khilafah. Hal ini sesuai dengan firman Allah:

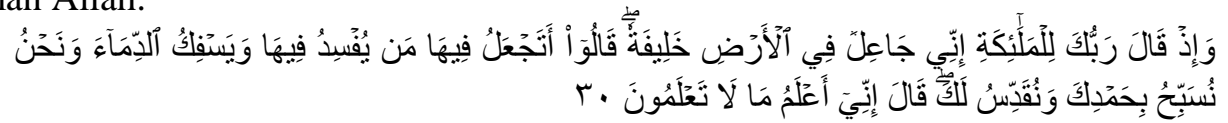
"Ingatlah ketika Tuhanmu berfirman kepada para Malaikat: "Sesungguhnya Aku hendak menjadikan seorang khalifah di muka bumi". Mereka berkata: "Mengapa Engkau hendak menjadikan (khalifah) di bumi itu orang yang akan membuat kerusakan padanya dan menumpahkan darah, padahal kami senantiasa bertasbih dengan memuji Engkau dan mensucikan Engkau?" Tuhan berfirman: "Sesungguhnya Aku mengetahui apa yang tidak kamu ketahui" (Q.S Al Baqarah : 30). ${ }^{69}$

Tema tata kelola perusahaan dalam ISR merupakan penambahan dari Othman et $a l^{70}$ dimana tema ini tidak bisa dipisahkan dari perusahaan guna memastikan pengawasan pada aspek syaraiah perusahaan. Secara formal corporate governance dapat didefinisikan sebagai sistem hak, proses, dan kontrol secara . keseluruhan yang ditetapkan secara internal dan eksternal atas manajemen sebuah entitas bisnis dengan tujuan untuk melindungi kepentingan-kepentingan stakeholder.

\footnotetext{
65Al_Qur'an, 30:41

66 Haniffa , R.,"Social Reporting Disclosure : An Islamic Perspective"... h. 137

${ }^{67}$ Othman, Rohana, Azlan Md Thani dan erlane K Ghani, "Determints of islamic social reporting... h. 19

${ }^{68}$ Haniffa dan Hudaib, ”Exploring the Ethical Identity of Islamic Banks..., 76: 97.

${ }^{69 \mathrm{Al}}$-Qur'an, 2:130

${ }^{70}$ Othman, Rohana, Azlan Md Thani dan erlane K Ghani, “Determints of islamic social... h. 19
} 
Informasi yang diungkapkan dalam tema tata kelola perusahaan adalah status kepatuhan terhadap syariah, rincian nama dan profil direksi, DPS dan komisaris, laporan kinerja komisaris, DPS, dan direksi, kebijakan remunerasi komisaris, DPS, dan direksi, laporan pendapatan dan penggunaan dana non halal, laporan perkara hukum, struktur kepemilikan saham, kebijakan anti korupsi, dan anti terorisme. ${ }^{71}$

\section{INDIKATOR ISLAMIC SOCIAL REPORTING INDEX SEBAGAI AKUNTABILITAS SOSIAL BANK UMUM SYARIAH}

Tabel 3.1

Indeks Islamic Social Reporting (ISR)

No

A. Pendanaan dan Investasi

1 Aktivitas yang mengandung riba (beban bunga dan pendapatan bunga)

2 Kegiatan yang mengandung Gharar (hedging, future on delivery trading/margin trading, arbitrage baik spot atau forward, short selling, pure swap, warrant)

3 Zakat (jumlah dan penyaluran)

$4 \quad$ Kebijakan atas keterlambatan pembayaran piutang dan penghapusan piutang tak tertagih

$5 \quad$ Kegiatan Investasi (secara umum)

6 Proyek Pembiayaan (secara umum)

B. Produk dan Jasa

7 Pernyataan DPS terhadap kehalalan produk dan jasa baru

\section{Skor}

6

1

Haniffa (2002) Othman et al (2009)

1 Haniffa (2002) Othman et al (2009)

Haniffa (2002) Othman et al (2009)

1 Othman et al (2009)

1 Haniffa dan Hudaib (2007)

1 Haniffa dan Hudaib (2007)

3

$1 \quad$ Haniffa dan Hudaib (2007)

\footnotetext{
${ }^{71}$ Othman, Rohana, Azlan Md Thani dan erlane K Ghani, “Determints of islamic social... h. 20
} 

8 Jenis dan definisi setiap produk
9 Pelayanan atas keluhan nasabah (bentuk, jumlah keluhan dan penyelesaian)

C. Karyawan

10 Jumlah Karyawan

11 Jam Kerja

12 Hari libur

13 Tunjangan Karyawan

14 Kebijakan Remunerasi

15 Pendidikan dan Pelatihan karyawan

16 Kesamaan peluang bagi seluruh karyawan

17 Apresiasi terhadap karyawan berprestasi

18 Kesehatan dan keselamatan karyawan

19 Keterlibatan karyawan di perusahaan

20 Tempat ibadah yang memadai

21 Waktu ibadah / kegiatan religius

22 Kesejahteraan karyawan

D. Masyarakat

23 Sedekah/donasi(Jumlah dan Penyaluran nya)

24 Wakaf (Jenis dan penyaluran)
1 Haniffa dan Hudaib (2007)

1 Haniffa dan Hudaib (2007)

1 Haniffa dan Hudaib (2007)

1 Haniffa (2002) Othman et al (2009)

1 Haniffa (2002) Othman et al (2009)

1 Haniffa (2002) Othman et al (2009)

1 Othman et al (2009)

1 Haniffa (2002) Othman et al (2009)

1 Othman et al (2009)

1 Haniffa dan Hudaib (2007)

1 Othman et al (2009)

1 Othman et al (2009)

1 Othman et al (2009)

1 Othman et al (2009)

1 Haniffa dan Hudaib (2007)

11

1 Haniffa (2002) Othman et al (2009)

1 Haniffa (2002) 
25 Qard hasan/pinjaman kebaikan

$1 \quad$ Haniffa (2002) (Jumlah dan Penyaluran)

26 Sukarelawan dari kalangan karyawan

$1 \quad$ Othman et al (2009)

27 Pemberian beasiswa sekolah

$1 \quad$ Othman et al (2009)

28 Pemberdayaan kerja para lulusan

$1 \quad$ Othman et al (2009) sekolah/kuliah (magang atau praktik kerja lapangan)

29 Pengembangan generasi muda

$30 \quad$ Peningkatan kualitas hidup masyarakat miskin

31 Kepedulian terhadap anak-anak

32 Kegiatan amal atau sosial (bantuan bencana alam, donor darah, sunatan masal, pembangunan infrastruktur, d11)

33 Menyokong kegiatan-kegiatan ksehatan, hiburan, olahraga, budaya, pendidikan dan keagamaan

\section{E. Lingkungan}

34 Konservasi lingkungan hidup

1 Haniffa (2002) dan Othman et al (2009)

35 Kegiatan mengurangi efek pemanasan global (minimalisasi

$1 \quad$ Othman et al (2009) polusi, pengelolaan limbah, pengelolaan airbersih, dll)

36 Pendidikan terhadap lingkungan hidup

$1 \quad$ Othman et al (2009)

37 Penghargaan dibidang lingkungan hidup

1 Haniffa dan Hudaib (2007)

38 Sistem manajemen lingkungan hidup

1 Othman et al (2009)

F. Tata Kelola Perusahaan 
39 Status kepatuhan terhadap syariah (opini DPS)

40 Pendapatan dan Penggunaan dana non-halal

Othman et al (2009)

41 Struktur kepemilikan saham

$1 \quad$ Othman et al (2009)

42 Kebijakan anti korupsi

1 Othman et al (2009)

43 Penerapan program anti pencucian uang dan pencegahan pendanaan terorisme

1 POJK No. 12/POJK.01/2017

44 Pemberian dana untuk kegiatan sosial dan kegiatan politik

POJK. No. 55/POJK. 03/2016

45 Penggunaan jasa akuntan publik dan kantor akuntan publik

1 POJK. No. 13/POJK.03/2017

46 Pelaksanaan sertifikat Treasuri dan penerapan kode etik pasar

PBI No. 19/5/PBI/2017

47 Penyampaian informasi nasabah asing terkait perpajakan

SEOJK No. 16/SEOJK.03/2017

48 Pelaporan dan pemantauan informasi debitur melalui sistem layanan informasi keuangan

49 Gerbang pembayaran Nasional

50 Pemblokiran Dana Nasabah

PBI No. 19/8/PBI/2017

1 SEOJK No. 38/SEOJK.01/2017

51 Perkara hukum

Othman et al (2009)

52 Rincian nama dan profil dewan komisaris

1 Othman et al (2009)

53 Kinerja komisaris (pelaksanaan

$1 \quad$ Othman et al (2009) tanggung jawab dan jumlah rapat)

54 Remunerasi dewan komisaris

$1 \quad$ Othman et al (2009)

55 Rincian nama dan profil dewan direksi

1 Othman et al (2009)

56 Kinerja direksi (pelaksanaan tanggung jawab dan jumlah rapat)

$1 \quad$ Othman et al (2009)

57 Remunerasi dewan direksi

$1 \quad$ Othman et al (2009) 


$\begin{array}{clcl}58 & \text { Rincian nama dan profil DPS } & 1 & \text { Othman et al (2009) } \\ 59 & \begin{array}{l}\text { Kinerja DPS (pelaksanaan tanggung } \\ \text { jawab dan jumlah rapat) }\end{array} & 1 & \text { Othman et al (2009) } \\ 60 & \begin{array}{l}\text { Remunerasi DPS } \\ \text { Total }\end{array} & 1 & \text { Othman et al (2009) }\end{array}$

(Sumber: dikembangkan untuk penelitian ini, data diolah, 2018

V. IMPLEMENTASI ISLAMIC SOCIAL REPORTING INDEX SEBAGAI AKUNTABILITAS SOSIAL BANK UMUM SYARIAH

\section{Tema Pendanaan dan Investasi (Finance and Investment Theme)}

Berdasarkan hasil skoring Indeks ISR tema pendanaan dan investasi periode 2013-2017 diperoleh rata-rata nilai indeks ISR setiap BUS sebagaimana ditunjukkan dalam grafik berikut ini:

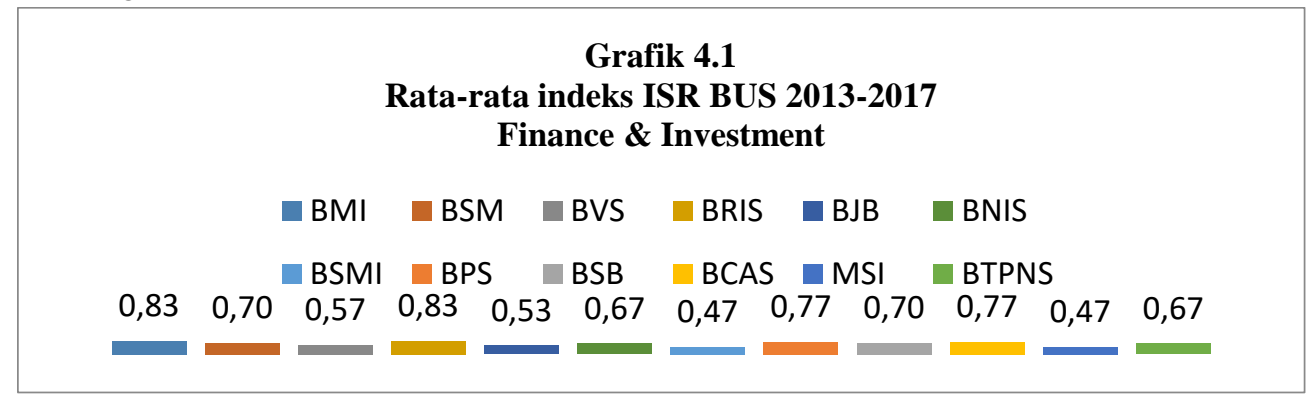

(Sumber: annual report BUS, data diolah, 2018)

Dari grafik 4.1 diatas, predikat tingkat pengungkapan ISR BUS 2013-2017 dengan tema pendanaan dan investasi adalah sebagai beikut: pertama, peringkat sangat informatif (81-100\%) yakni, BMI dan BRIS. Kedua, predikat informatif (66$80 \%$ ) yakni, BSM, BNIS, BPS, BSB, BCAS dan BTPNS. Ketiga, predikat kurang informatif (50-66\%) yakni, BVS dan BJB. Keempat, predikat yang tidak informatif $(<50 \%)$ yakni, BSMI dan BTPNS.

\section{Tema Produk dan Jasa (Product and Service Theme)}

Berdasarkan hasil skoring Indeks ISR tema produk dan jasa periode 20132017 diperoleh rata-rata nilai indeks ISR setiap BUS sebagaimana ditunjukkan dalam diagram berikut ini. 


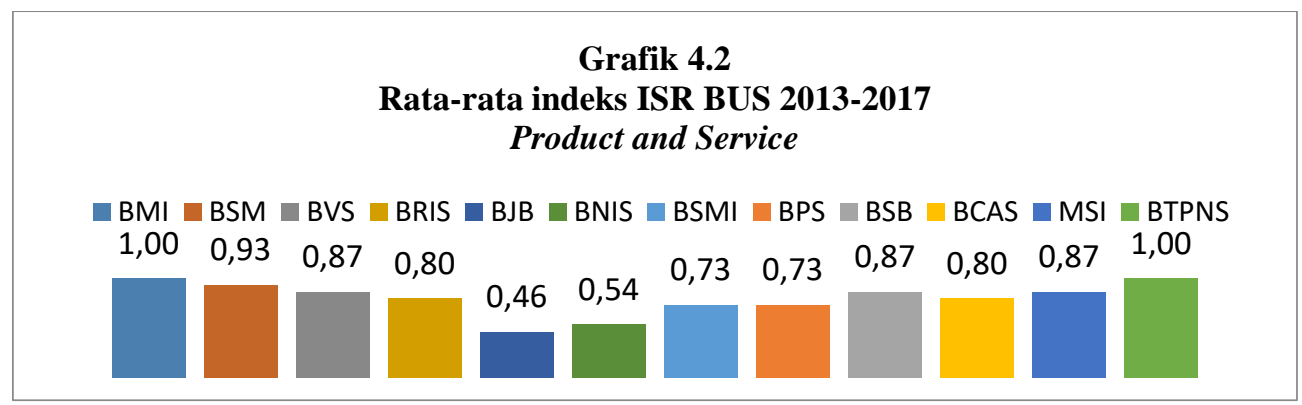

(Sumber: annual report BUS data diolah, 2018)

Dari grafik 4.2 diatas, predikat tingkat pengungkapan ISR BUS 2013-2017 dengan tema produk dan jasa adalah sebagai beikut: pertama, peringkat sangat informatif (81-100\%) yakni, BMI, BSM, BVS, BSB, MSI dan BTPNS. Kedua, predikat informatif (66-80\%) yakni, BRIS, BSMI, BPS, dan BCAS. Ketiga, predikat kurang informatif (50-66\%) yakni, BNIS. Keempat, predikat yang tidak informatif $(<50 \%)$ yakni, BJB.

\section{Tema Karyawan (Employess Theme)}

Berdasarkan hasil skoring Indeks ISR tema produk dan jasa periode 20132017 diperoleh rata-rata nilai indeks ISR setiap BUS sebagaimana ditunjukkan dalam diagram berikut ini.

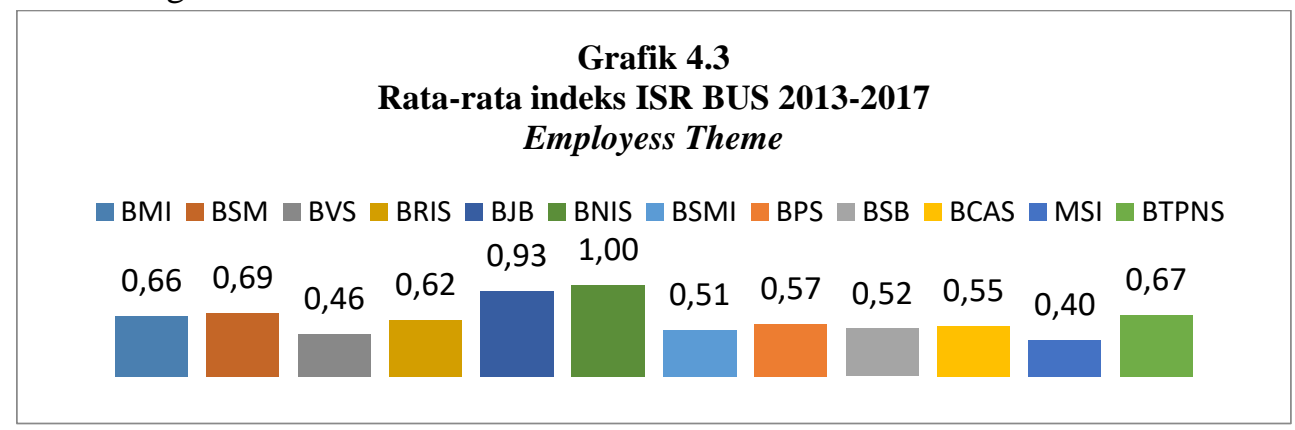

(Sumber: annual report BUS data diolah, 2018)

Dari grafik 4.3 diatas, predikat tingkat pengungkapan ISR BUS 2013-2017 dengan tema karyawan adalah sebagai berikut: pertama, peringkat sangat informatif (81-100\%) yakni, BNIS dan BJB. Kedua, predikat informatif (66-80\%) yakni, BMI, BSM, dan BTPNS. Ketiga, predikat kurang informatif (50-66\%) yakni, BRIS BSMI, BPS, BSB dan BCAS. Keempat, predikat yang tidak informatif $(<50 \%)$ yakni, BVS dan MSI.

\section{Tema Masyarakat (Society Theme)}

Berdasarkan hasil skoring Indeks ISR tema produk dan jasa periode 20132017 diperoleh rata-rata nilai indeks ISR setiap BUS sebagaimana ditunjukkan dalam diagram berikut ini. 


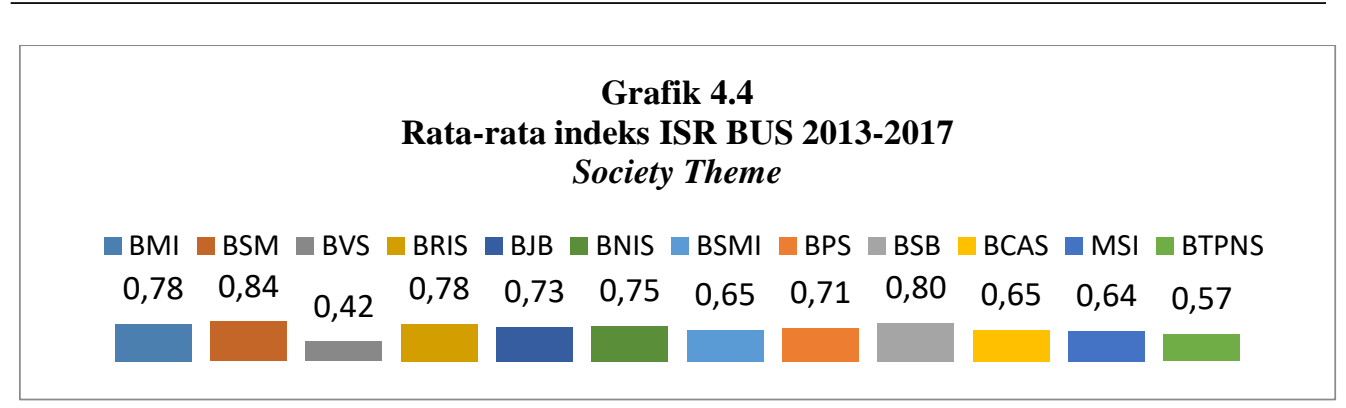

(Sumber: annual report BUS data diolah, 2018)

Dari grafik 4.4 diatas, predikat tingkat pengungkapan ISR BUS 2013-2017 dengan tema masyarakat adalah sebagai berikut: pertama, peringkat sangat informatif (81-100\%) yakni, BSM. Kedua, predikat informatif (66-80\%) yakni, BMI, BRIS, BJB, BNIS, BPS, dan BSB. Ketiga, predikat kurang informatif (50$66 \%$ ) yakni, BSMI, BCAS, MSI dan BTPNS. Keempat, predikat yang tidak informatif $(<50 \%)$ yakni, BVS.

\section{Tema Lingkungan (Environment Theme)}

Berdasarkan hasil skoring Indeks ISR tema produk dan jasa periode 20132017 diperoleh rata-rata nilai indeks ISR setiap BUS sebagaimana ditunjukkan dalam diagram berikut ini.

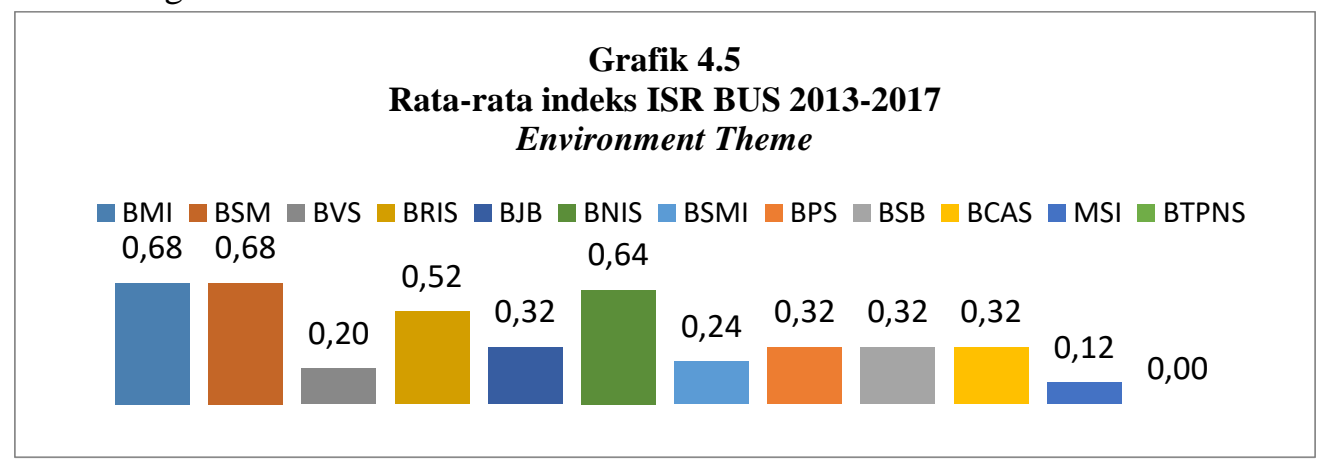

(Sumber: annual report BUS data diolah, 2018)

Dari grafik 4.5 diatas, predikat tingkat pengungkapan ISR BUS 2013-2017 dengan tema lingkungan adalah sebagai berikut: pertama, predikat informatif (66$80 \%$ ) yakni, BMI dan BSM. Kedua, predikat kurang informatif (50-66\%) yakni, BRIS dan BNIS. Ketiga, predikat yang tidak informatif $(<50 \%)$ yakni, BVS, BJB,BSMI, BPS, BSB, BCAS, MSI dan BTPNS. 


\section{Tema Tata Kelola Perusahaan (Corporate Governance Theme)}

Berdasarkan hasil skoring Indeks ISR tema produk dan jasa periode 20132017 diperoleh rata-rata nilai indeks ISR setiap BUS sebagaimana ditunjukkan dalam diagram berikut ini.

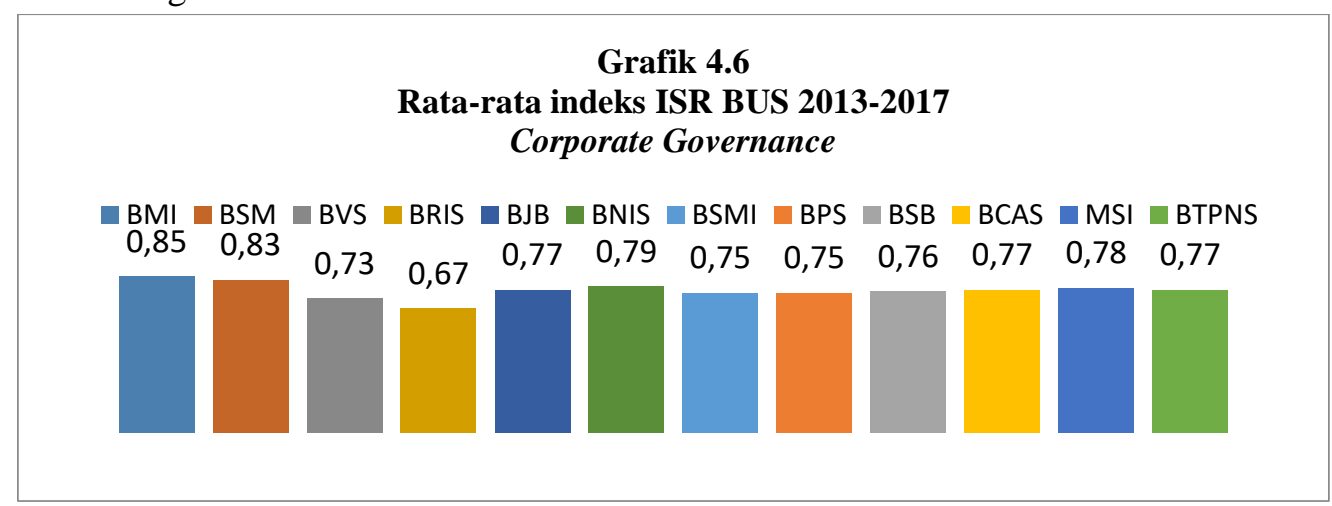

(Sumber: annual report BUS data diolah, 2018)

Dari grafik 4.6 diatas, predikat tingkat pengungkapan ISR BUS 2013-2017 dengan tema karyawan adalah sebagai berikut: pertama, peringkat sangat informatif (81-100\%) yakni, BMI dan BSM. Kedua, predikat informatif (66-80\%) yakni, BVS, BRIS, BJB, BNIS, BSMI, BPS, BSB, BCAS, MSI dan BTPNS.

\section{KESIMPULAN}

Model pengungkapan ISR menurut othman et. al., terdiri dari 6 indikator: Finance \& Investment, Products and Services, Employees, Community Involvememt, Environment dan Corporate Governance. Indikator-indikator ini kemudian dikembangkan lebih detail oleh beberapa peneliti selanjutnya, salah satunya Gustani yang menggabungkan konsep model pengungkapan ISR haniffa dan othman yang disesuaikan dengan peraturan Bank Indonesia sehingga didapat 60 sub item pengungkapan ISR.

Bila diukur dengan indeks ISR dengan 60 sub item, maka dapat dihasilkan data empiris tingkat pengungkapan ISR pada BUS di Indonesia periode 2012-2017. Pertama tema pendanaan dan investasi terdapat 6 BUS yang kurang informatif, kedua pada tema produk dan jasa yang kurang informatif adalah BRI Sy, ketiga pada tema karyawan terdapat 5 BUS yang kurang informatif, keempat pada tema Masyarakat terdapat 6 BUS yang kurang informatif, , kelima pada tema lingkungan terdapat 9 BUS yang kurang informatif. Walaupun sebenarnya skor indeks ISR yang rendah (kurang informatif) tidak dapat diartikan bahwa perusahaan tersebut tidak melakukan pengungkapan tanggung jawab sosial secara syariah dengan baik karena terdapat dua kemungkinan, yaitu perusahaan tersebut melakukan tanggung jawab sosial secara syariah akan tetapi tidak diungkapkan dalam laporan-laporannya atau 
perusahaan tersebut memang tidak melakukan tanggung jawab sosial secara syariah. Hasil penelitian dapat dijadikan sebagai bahan pertimbangan untuk perusahaanperusahaan terkait pentingnya pengungkapan ISR dalam laporan keuangan mereka, dan menjadi pertimbangan pemerintah (khususnya Bank Indonesia atau Otoritas Jasa Keuangan) untuk membuat standardisasi terkait tema ISR pada BUS.

\section{DAFTAR PUSTAKA}

Aribi, Zakaria Ali.Simon Gao, (2010) "Corporate social responsibility disclosure: A comparison between Islamic and conventional financial institutions", Journal of Financial Reporting and Accounting, Vol. 8 Issue: 2, pp.72-91, https://doi.org/ 10.1108/19852511011088352

, (2011) "Narrative disclosure of corporate social responsibility in Islamic financial institutions", Managerial Auditing Journal, Vol. 27 Issue: 2, pp.199-222, https://doi.org/10. 1108/ 02686901211189862

Dusuki, Asyraf Wajdi and Nurdianawati Irwani Abdullah(2007)"Islamic corporate Social Responsibility (ICSR): Kajian Teoritis", The American Journal of Islamic Social Sciences 24:1. http://irep.iium.edu.my/2209/1/dusukiabdullah-maqasid\%5B1\%5D.pdf

Dusuki, Asyraf Wajdi and Nurdianawati Irwani Abdullah(2007)The American Journal of Islamic Social Sciences

24:1 http://irep.iium.edu.my/2209/1/dusuki-abdullahmaqasid\%5B1\%5D.pdf

Farook, Sayd.M. Kabir Hassan, Roman Lanis, (2011) "Determinants of corporate social responsibility disclosure: the case of Islamic banks", Journal of Islamic Accounting and Business Research, Vol. 2 Issue: 2, pp.114-141, https://doi.org/10.1108/ 17590811111170539

Finarti, Aan dan Purnama Putra (2015) dengan judul “ Maqoshid Al-Syari'ah Terhadap pelaksanaan CSR Bank Islam: Studi Kasus pada BRIS" SHARE: vol. 4 https://jurnal.ar-raniry.ac.id/index.php/Share/article/view/724

Haniffa, R. \& Hudaib, M. J Bus Ethics (2007)" Exploring the Ethical Identity of Islamic Banks via Communication in Annual Reports "76: 97. https://doi.org/10.1007/s10551-006-9272-5

Haniffa, R. (2002). Social Reporting Disclosure: An Islamic Perspective. Indonesian Management and Accounting Research.

Kamla, Rania.Hussain G. Rammal, (2013) "Social reporting by Islamic banks: does social justice matter?", Accounting, Auditing \& Accountability Journal, Vol. 26 Issue: 6, pp.911-945, https://doi.org/10.1108/AAAJ-03-2013-1268

Kusnasari, Sintia Devi dan Lintang Venusita (2014), Pelaksanaan Corporate Social Responsibility yang terdapat pada Perbankan Syariah dalam Prespekstif Shariah Enterprise studi kasus pada Bank BRI Syariah dan Bank Mandiri Syariah $\quad$ Vol $3, \quad$ No (2014)http://jurnalmahasiswa.unesa.ac.id/index.php/jurnalakuntansi/article/view/11215 
Mashudi, Mashudi. "Perilaku Dan Budaya Konsumen Madura Dalam Dinamika Etika Bisnis Syariah." Al-Insyiroh: Jurnal Studi Keislaman 2.2 (2018): 133149.

Meutia, Inten, (2010) Shari'ah Enterprise Theory sebagai Dasar Pengungkapan Tanggungjawab Sosial Bank Syariah.Doctor thesis, Universitas Brawijaya.http://repository.ub.ac.id/151/

Muchlis, Saiful dan Anna Sutrisna Sukirman (2016) dengan judu " Maqoshid Syariah dalam Corporate Social Responsibility di BMI" Jurnal Akuntansi Multiparadigma, Volume 7, Nomor 1, April 2016, Hlm. 120130http://journal.uinalauddin.ac.id/index.php/assets/article/viewFile/2908/ $\underline{2780}$

Othman, Rohana, Azlan Md Thani dan erlane K Ghani (2009), "Determints of islamic social reporting Among Top shariah-approved Comapnies in Bursa malaysia" Research Journal of International Studies Issue 12 oktober, 2009 https://www.researchgate.net/profile/Rohana Othman/publication/228783 690_Determinants_of_Islamic_Social_Reporting_Among_Top_Shari\%27 a-Approved_Companies__ in_Bursa__ Malaysia/ links/5552c44e08aeaaff3bf00119/Determinants-of-Islamic-Social-

Reporting-Among-Top-Sharia-Approved-Companies-in-BursaMalaysia.pdf

Prasetyoningrum, Ari Kristin(2016) “Pengaruh Kinerja Keuangan Dan Dewan Pengawas Syariah Terhadap Pengungkapan Islamic Social Reporting Pada Perbankan Syariah Di Indonesia" Laporan Penelitian. Fakultas Ekonomi dan Bisnis Islam UIN Walisongo.

Taufik dkk., .Pengaruh Islamic Governance Score, Laverage Dan Profitabilitas Terhadap Islamic Social Reporting Index Pada Bank Umum Syariah di Indonesia”,. Jurnal manajemen dan bisnis Sriwijaya, Vol. 3 No. 2, 2015

Assegaf, Yasmin Umar dkk., "Bank Syariah Di Indonesia: Corporate Governance Dan Pengungkapan Pertanggungjawaban Sosial Islami (Islamic Social Responsibility Disclosure)", (Unissula: Conference In Business, Accounting And Management (CBAM). 2012

Desy Dkk., "Analisis Pengungkapan Corporate Social Responsibility Perbankan Syariah Indonesia Berdasarkan Islamic Social Reporting Index", (Universitas Muhammadiyah Malang: Kompartemen Vol. XV, No. 2, 2017 Suparyanto, Didik. "Prospek Perbankan Syariah di Indonesia." Al-Insyiroh: Jurnal Studi Keislaman 2.2 (2018): 170-181.

Rama, Ali. "Analisis Determinan Pengungkapan Islamic Social Reporting: Studi Kasus Bank Umum Syariah Di Indonesia”, (Equilibrium: Jurnal Ekonomi Syariah, Vol. 2, No. 1, 2014

Cahya, Bayu Tri. "Islamic Social Reporting: Ditinjau Dari Aspek Corporate Governance Strength, Media Exposure dan Karakteristik Perusahaan Berbasis Syariah di Indonesia Serta Dampaknya Terhadap Nilai Perusahaan"( Disertasi, Universitas Islam Negeri Sumatera Utara Medan, 2017 
Khoirudin, Amirul. "Corporate Governance Dan Pengungkapan Islamic Social Reporting Pada Perbankan Syariah Di Indonesia", (Universitas Negeri Semarang: Accounting Analysis journal, 2013

Purwadi, Muhammad Imam.(2017) Konsep dan Corporate Social Responsibility (CSR) Pada Perbankan Syariah. Jatiswara, [S.1.], v.31, n.3, p.401-415, oct.2017.

at: $\langle$ http://jatiswara.unram.ac.id/index.php/js/article/view/58 $>$.Date accessed: 21 dec. 2017.

Santosoa, Arif Lukman, Zaki Murtadho Dhiyaul-Haq (2017), "Determin Pengungkapan Islamic Social Reporting pada Bank umum Syariah di Indonesia" (2017) Junal Dinamika Akuntansi dan Bisnis (JDAB) Vol. 4(2), 2017, pp 125-142. Diakses 21 november 2017 https://doi.org/10.24815/JDAB.V412.6421

Sofyani, Hafiez dan Anggar Setiawan (2017), "Perbankan Syariah Dan Tanggungjawab Sosial:Sebuah Studi Komparasi Indonesia Dan Malaysia Dengan Pendekatan Islamic Social Reporting Index Dan Global Reporting Initiative Index" (2011), JDA: Jurnal Dinamika Akuntansi Vol. 4, No. 1, Maret 2012, pp.36-46. ISSN 2085-4277 diakses 20 november 2017. http://journal.unnes.ac.id/index.php/jda

Sofyani, Hafiez, Ihyaul Ulum, Daniel Syam dan Sri Wahjuni L (2017), "Islamic Social Reporting Index Sebagai Model Pengukuran Kinerja Sosial Perbankan Syariah (Studi Komparasi Indonesia Dan Malaysia)" (2012) JDA: Jurnal Dinamika Akuntansi Vol. 4, No. 1, Maret 2012, pp.36-46. ISSN 2085-4277 diakses $20 \quad$ november 2017. http://journal.unnes.ac.id/index.php/jda

Trisnawati, Rina (2012) "Pengaruh Ukuran Perusahaan, Profitabilitas, Leverage, Ukuran Dewan Komisaris Dan Kepemilikan Manajerial Terhadap Pengungkapan Corporate Social Responsibility (CSR) Industri Perbankan Di Indonesia”. (2014) : Jurnal Ilmiah Program Studi Akuntansi, ISBN: 978602-70429-2-6. Fakultas Ekonomi dan Bisnis Universitas Muhammadiyah Surakarta. Diakses 07 November 2017

Gustani, "Model pelaporan kinerja sosial perbankan syariah: islamic social reporting index (indeks ISR) di Indonesia", (Jurnal Akuntansi dan Keuangan Islam 1, No. 2, 2013 